\title{
不動産関係判例の動き [17]
}

概 況

今回は, 判例時報1291 1295号, 判例タイムズ 679 683号の中から 9 件の判決例を選んだ。1は 建物の表示登記の申請を却下した登記官の過失を 否定した事例， 2 は契約の解釈か㵍題となった事 例, 3 㳻地上の建物の賃借人は地代の弁済につ いて法律上の利害関係を有すると解した事例であ る。4 は賃貸借の解除には正当事由があると判断 した事例， 5,6 はマンションの紛争化関する事 例, 7 はいわりる原野商法を違法とした事例， 8 は詐害行為取消権, 9 は譲渡担保に関する事例で ある。

1. 建物の表示登記と登記官の過失

\section{損害賠償請求事件}

最高裁(二小)昭和62.11.13判決 破蓑自判, 判夕 680-115

$\mathrm{X}$ （被上告人）は $\mathrm{A}$ から購入した建物の表示登 記及び所有権保存登記を同時に申請したが, 登記 官は表示登記の申請に欠陥か認められたため, そ の登記申請を却下し, 登記嘱託に基づく登記を先 にした。Xは登記官の違法な行為により損害を被 ったとして，国に詨して損害賠償を請求した。原 審（福岡高裁昭和58.6.30判決）は, 登記官の過 失を認少, Xの請求を一部認容したが, 本判決 は，原判決を破棄し，Xの請求老否定した。

本判決は, 「不動産登記法93条 2 項は, 建物の 表示の登記の申請書には申請人の所有権を証する 書面を添付するてとを要するものとしているとて ろ，被上告人の建物の表示登記の申請書に添付し

\section{不動産判例研究会}

た所有権を証する書面の記載内容は真実と符合し ないものであり，かかる書面を添付していた同申 請の欠陥は，即日補正し得ない性質のものである から, 被上告人の表示登記の申請は法49条10号, 8 号により却下を免れなかったというほかない」 と判示した。

2. 土地貨借権の無断譲渡と契約の解釈

\section{建物収去土地明渡等請求事件}

最高裁 ( 1 小) 昭和63.9.8判決 破棄差戻, 判時 1291-60, 判夕681-107

$\mathrm{X}$ (上告人) は，自己の所有地を $\mathrm{Y}_{1}$ に賃貸し， Y $\mathrm{Y}_{1}$ その地上に建物を所有していた。 $\mathrm{Y}_{1}$ はての 建物を亡き S 亿売り渡す契約をしたとてろ，Xは 貨借権の無断譲渡を理由に，Y $\mathrm{Y}_{1}$ らに建物収去土 地明渡等の請求をした。本件では，建物売買契約 の当事者間では売買代金 750 万円の 4 割に相当す る 300 万円が手付金として契約時に支払うべき約 定になって扣り，かつ，同手付金は約定ど扣り支 払済みであった。また，買受人である亡き $\mathrm{S}$ は， 同約定ど扔り契約締結時に家族と本件建物に入居 して扣り，しかも亡き S は入居後本件建物に造作 工事を施していた。原審は，本件建物の所有権移

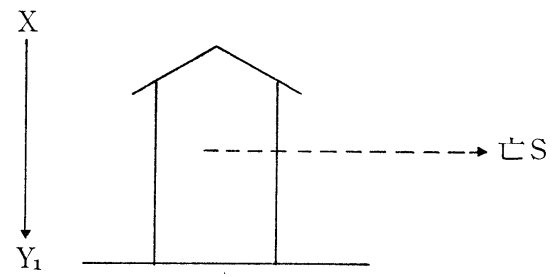


転及び本件土地の賃借権の譲渡の効力の発生につ いて停止条件が付されていたものと解釈し，上告 人のした本件土地の賃貸借契約解除の意思表示は 民法 612 条 1 項の賃借権の譲渡がないのになされ たもので無効であると判断した。

本判決は, 原判決を破棄し, 売買契約の約定及 び契約当事者の行為から判断して, 本件建物の売 渡及び本件土地の賃借権の譲渡の効力発生は売買 契約締結と同時であると解した。

\section{3. 地代についての第三者弁済の利益}

\section{執行文付与に対する異議事件}

最高裁（二小）昭和63.7.1判決 上告棄却, 判夕 680-119

$\mathrm{Y}$ (土地所有者)， $\mathrm{X}$ 万（同地上の $\mathrm{A}$ 所有建物 の賃借人) 及びA との間に，「地代不払があった ときは，Aは建物を収去し土地を明渡す，Xは建 物から退去し土地を明渡す」旨の執行文の付与さ れた和解調書がある場合に，XはAの地代不払前 に弁済供託し，執行の不許を請求した。

本判決は，「建物賃借人と土地賃貸人との間に は直接の契約関係はないが，土地賃借権が消滅す るときは，建物賃借人は土地賃貸人に対して，賃 借建物から退去して土地を明け渡すべき義務を負 う法律関係にあり，建物賃借人は，敷地の地代を 弁済し，敷地の賃借権が消滅するてとを防止する ことに法律上の利益を有する」として, 借地上の 建物の賃借人はその敷地の地代の弁済について法 律上の利害関係を有すると解した。

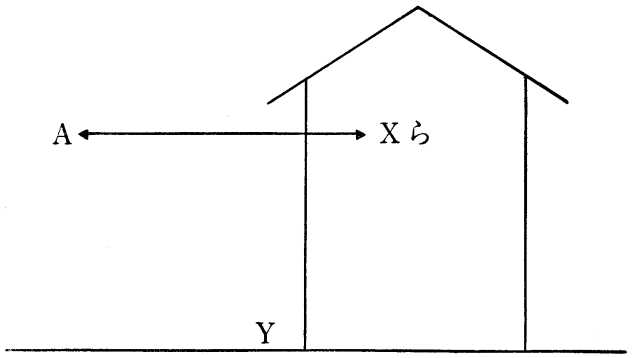

4. 貨貸借の解除と正当事由

\section{建物明渡等請求控訴事件}

横浜地裁昭和 63.2.12 判決 取消, 一部認容（控

訴), 判時1291-108

$\mathrm{X}$ （控訴人）が，鎌倉に所有する 2 階建共同住 宅 (所在地は鎌倉) の 1 階の一部で喫茶店を営む $\mathrm{Y}$ （被控訴人）に対して，正当事由具備による建 物賃貸借契約の解除, 同建物明渡等を請求した事 案。

本判決は，被控訴人に対する控訴人による相当 額の明渡料の支払を条件とした解約申入に基づく 明渡請求を認めてよいとし，明渡料として 400 万 円が相当と判断した。

5. マンション管理組合の仮理事長の選任

\section{仮理事長選任申請事件}

大阪地裁昭和63.2.24決定 認容 (確定)，判時 12 93-124, 判夕679-181

大阪市内の分譲マンション（地上11階地下1階, 202戸)では，いわゆる地上げ屋から 164 戸を買い 占められて扣り，管理組合の総会で理事全員が後 任理事を選任しないまま辞任したため，利害関係 人である区分所有者らの申請に基づき，管理組合 の管理者として仮理事長の選任を認めた事例。

6. マンション規約違反

\section{構築物撤去請求事件}

京都地裁昭和63.6.16判決 認容 (控訴), 判時12 95-110

マンション(鉄筋コンクリート造陸屋根 5 階建) 4 階の区分所有者である被告らがバルコニーにサ ンルーム等を設置したてとが，本件マンション規 約によって遵守を義務づけられた，目的に従った 用法による使用に違反すると認め，X（本件マン ション入居者全員を組合員として構成された権利 能力なき社団）からのその撤去請求を認めた事 例。 
7. 不動産の売買とクーリング・オフ

\section{損害賠償請求事件}

大阪地裁昭和63.2.24判決 一部認容 (控訴), 判 時1292-117

Y会社 (宅地建物取引業者) ふら違法に土地を 購入させられたXに，宅地建物取引業法 37 条の 2 第 1 項に基づくクーリング・オフ権による売買契 約の解除を認め, さらに，Y弓（同会社及び同会 社代表取締役）に対する民法709 条の不法行為に 基づく損害賠償請求を認めた事例。

本判決は, 本件売買契約勧誘の違法性につい て, 次のように述べている。

「Y会社の従業員がXに対して行った勧誘行為 は，一方で本件土地を別荘用に適する土地である としながら，てれを直ちに利用することを目的と せず，近い将来の土地值上りによる転売利益取得 を主たる目的として，その購入をすすめたもので あるが，その転売利益取得の可能性について，本 件土地の評価額は実際には22万円（1 坪あたり約 7,326円)程度にすぎないのに，乙れが1坪あたり 14万円ないし15万円であるかのような虚為の説明 をして，本件売買代金 225 万円（1坪あたり 7 万 5,000円)でも時価よりはるかに安いように装って いたとと,さらに，実際は社町の開発計画, 工場 の進出, 交通の利便等はいずれも本件土地の価格 に近い将来影響を及ぼす可能性が全くないうえ に，本件土地の売買代金額自体が時価より著しく 高額で，てれ以上の価格に值上りすることは到底 考无られないのに，いかにも右事態によって本件 土地が $1 ， 2$ 年後にも売買価格より大幅に值上り するかの如く断定的な説明をしたてと，また，右 のと打り，売買代金額以上の価格で転売すること は困難であると思われるのに，1年後の転売を確 約してXに出捐金額の回収が容易であるかのよう に誤信させたてと，しかも，右勧誘に当っては， ことさら若い独身男性で不動産取引や投資取引に 知識・経験がないと思われる者を客として選んだ
うえ若い女子従業員を使って関心を引き，現地へ 案内すると同時に十分な考慮の余裕を与えずに現 地に近い旅館等で契約締結に至るまで同様の锥誘 説得をくり返していたてとなど，不動産取引，投 資取引に知識・経験の乏しいXをして虚偽の説明 を䛊信させるよう意図的な勧誘方法をとっていた てとが認められるのであって, かかる勧誘方法 は, 不動産業者として許容される顧客獲得のため の正常な宣伝, 勧誘行為の範囲を著しく逸脱した ものであって，違法なものというべきである」。

\section{8. 譲渡担保契約等と詐害行為}

\section{詐害行為取消請求事件 \\ 最高裁（三小)昭和63.7.19判決 破棄差戻，判夕 683-56}

本件は, 抵当権の設定されている不動産につい て, 当該抵当権者以外の者との間にされた代物弁 済予約及び譲渡担保契約が詐害行為に該当する場 合に扔いて，一般債権者からの詐害行為取消の範 囲及び方法はどのように行われるべきであるかが 問題となった事案である。原審は，本件代物弁済 予約及び譲渡担保契約は詐害行為として取り消さ れるべきであるとしたうえ，同予約等は本件不動 産を一括してその対象としたものであって不可分 のものであるから，X（被上告人）は同行為の全 部につき取消権を行使して現物返還を求めること ができるとし，同予約等に係る所有権移転請求権 仮登記及び所有権移転登記の抹消登記手続請求を 認容した第一審判決を正当として控訴棄却の判決 をした。

しかし最高裁判所は，同不動産が不可分のもの であって，当該詐害行為の後に并済等によって同 抵当権設定登記等が抹消されたようなときは，そ の取消は，同不動産の価額から同抵当権の被担保 債権額を控除した残額の限度で価格による賠償を 請求する方法によるべきであると判断し，原審の 詐害行為取消の範囲及び方法に係る判断は，是認 するととができないとした。 
その理由として，「詐害行為取消権は，債権者 の共同担保を保全するため, 詐害行為により逸出 した財産を取り戻して債務者の一般財産を原状に 回復させようとするものであるから, その取消は, 本来, 債務者の詐害行為により減少された財産の 範囲にとどまるべきものであり，その方法は，逸 出した財産自体の回復が可能である場合には，で きるだけてれによるべきであるとてろ，詐害行為 の目的不動産に抵当権が付着している場合には， その取消は, 目的不動産の価額から同抵当権の被 担保債権額を控除した残額の部分に限って許され るが，右の場合に扔いて，その目的不動産が不可 分のものであって，付着していた抵当権の設定登 記等が抹消されたようなときには, 逸出した財産 自体を原状のまま回復するととが不可能若しくは 著しく困難であり，また，債務者及び債権者に不 当に利益を与える結果になるから，てのようなと きには，逸出した財産自体の返還に代えてその価 格による賠償を認めるほかないのである」と述べ ている。

9. 譲渡担保の実行とその効果
高松高裁昭和63.3.31判決 取消, 変更 (確定), 判夕681-159

$\mathrm{X}_{1}$ はY $\mathrm{Y}$ から借り受けていた金銭債務の担保と して本件動産及び営業権につき譲渡担保を設定し ていたが， $\mathrm{X}_{1}$ が期日に弁済をしなかったので， Yは動産及び営業権が自己に帰属したとして動産 の引渡及び営業権の確認を請求した。 本判決は，譐渡担保権の実行にあたっては，担 保権の私的実行に関する一般共通準則として仮登 記担保契約に関する法律 2 条の類推適用が相当で あるとして，Y（被控訴人）は一定期間経過時に 扣ける本件動産及び営業権を適正に評価した価額 及び被担保債権の額等同法 2 条 2 項所定の事項を 明らかにしたうえ，同価額が被担保債権の額等を 超えるときはその額即ち清算金の見積額を控訴人 会社 $\left(\mathrm{X}_{1}\right)$ 亿通知すれば，同通知到達後 2 月を経 過したときに，本件動産及び営業権は確定的に被 控訴人に移転の効力を生ずると判断した。そのう えで, 本判決は被控訴人は上記手続の主張立証を していないから，本件動産の引渡及び控訴人会社 との間に扔いて本件営業権を被控訴人が有するて との確認を求めるてとはできないと判断した。

\section{動産引渡等請求控訴事件}

